\title{
Management of Arthavakshaya - A Case report
}

\author{
Case Report
}

\section{Shriniwas Jadhav1*, Asokan V², Manjusha Karkare³}

\author{
1. Ph.D scholar \& Associate Professor, 2. Professor, 3. Professor and HOD, \\ Department of Ph.D Studies Prasuti Tantra and Stree Roga, \\ Parul Institute of Ayurved, Parul University, Vadodara.
}

\begin{abstract}
Artavakshaya can be compared to Oligomenorrhoea or Hypomenorrhoea. It is a case study of an unmarried female patient aged 20 years, who presented with complains of irregular menses since 5 to 6 years, amenorrhea of 2 months, painful menstruation, associated with constipation. She took allopathic treatment but could not find the result, so approached Parul Ayurved Hospital, Vadodara for management. Looking into the severity, Samshodhana that is Matra basti and oral medications was planned for the patient. After treatment, patient got menses on $4^{\text {th }}$ day of treatment and also her next menses came on regular time.
\end{abstract}

Key Words: Ayurveda, Artavakshaya, Matra Basti.

\section{Introduction}

Artavakshaya, in a condition associated with pain associated with menstruation along with backache, pain in groins, stiffness, but no abnormality of menstruation other than perhaps a decrease in the amount of flow or the duration. It is a common clinical complaint in reproductive aged women with a prevalence of oligomenorrhea $11.3 \%$ (1) which has multiple causative factors of nutritional deficiency, hormonal factors, emotional and stress factors and psycho-sexual factors. Here is an attempt to study the case of Artavakshaya with Ayurveda treatment modalities like Matrabasti and oral medications.

\section{Case report}

A 20 years old unmarried female patient came to OPD of and Prasuti tantra and Stree Roga Parul Ayurved Hospital, Vadodara, on 29/11/2019 with complaints of irregular menses for 4-5 years, Amenorrhoea of 2 months with associated complaints of lower abdominal pain and constipation on and off. Patient had regular cycles earlier but in the past 4-5 years she is having irregular menses of interval $45-60$ days. Patient had taken oral medicine for the same but was not relieved hence came to Parul Ayurved hospital. Patient was thoroughly examined and detailed history was taken, she was admitted for Matrabasti and further management.

\section{* Corresponding Author:}

\section{Shriniwas Jadhav}

Associate Professor,

Dept of Prasuti Tantra and Stree Roga,

Parul Institute of Ayurveda,

Parul University, Limda. Vadodara, Gujarat. India.

Email Id: shriniwasdjadhav@gmail.com

\section{Menstrual History}

LMP-29/9/19. Duration 4-5 days. Interval 40-60 days. Irregular, painful with passage of clots with average 2 pads soaked per day.

\section{Past menstrual history}

Menarche at 11 years of age. Duration of menses 4-5 days, interval of 28-30 days regular with 2-3 pads soaked per day, painless and without passage of clots.

Past obstetric history

Unmarried female

\section{Past medical history}

Not significant

Past family history

No history of same complaints in the family.

\section{General examination}

General condition- fair: Built- Moderately built: Nourishment- Moderately nourished, Pallor-Absent: Oedema-Absent: Nails-No clubbing: Cyanosis-Absent: Icterus -Absent: Lymphadenopathy-Absent: P- 78/min: BP-110/70 mmHg: RR-18/min: Height-148: Weight-42kgs: BMI- $19.2 \mathrm{~kg} / \mathrm{m}^{2}$.

\section{Systemic examination}

- RS- Clear

- CVS- S1S2 heard

- CNS- conscious well oriented,

- P/A: Soft,Non-tender, No organomegaly.

\section{Vayaktika Vruttanta}

Diet- mixed Appetite-normal, Bowel: Constipated, Bladder Frequency- 5-6 times/day \& 0-1/ night Sleep- Sound, Habit- Coffee 2 times / day 


\section{Rogi Pariksha}

Prakruti - VataPittaja: Vikruti- Vata, Pitta, Sara - Madhyam, Sanhanan-Madhyam, Praman -148 cm wt- $42 \mathrm{~kg}$, Satmya-Madhyam, Satva -Madhyam, Aahar shakti-Madhyam, Vyayama shakti-Madhyam, Vaya - Madhyam, Jihwa - Samaavastha.

Yoni Pariksha: Inspection of external genitalia and vulva: no itch marks, no prolapse, no discharge, no oedema was observed. External urethral meatus was non inflamed. Stress incontinence and dribbling of urine was not noted.

P/S Examination: Vaginal wall was healthy, cervix healthy, no excessive discharge, no dryness, no polyp growth, normal in size, not eroded. Uterus anteverted anteflexed, normal in size, adnexa not palpable.

Investigations: (Done on First Visit)

- USG Pelvis: Uterus Anteverted, Ovaries Normal, Nebothian Cyst Of $1.2 \times 1 \mathrm{Cm}$ in Anterior Lip of Cervix.

- CBC Report: Hb: 12.7gm \%; WBC: 8600 cu.mm; Platelets: 2.32 Lakh

- Hormonal assay: not done (Patient not affordable)

- Nidana: Katu amla lavana aahara sevana (vata pittakara ahara sevana)

- Samprapti: Vatapitta Vrudhhi Leading to rasa kshaya and artava kshaya.

- Upshaya: Ushna dravya upashaya

- Anupashaya: Sheeta dravya

\section{Differential Diagnosis:}

Ksheena Artava Dushti; Arajaska Yoni Vyapad; Artava Kshaya

\section{Diagnosis:}

Artavakshaya

\section{Treatment given}

Table 1: Treatment Plan

DATE TREATMENT

Matra Basti with Tila taila along with Saindhava lavan $3 \mathrm{gms}=40 \mathrm{ml}$ given OD Daily for 3 days

29-11-2019

Rajah Pravartini vati 2 TDS A/F with water

Aloes compound $1 \mathrm{BD} \mathrm{A} / \mathrm{F}$ with water Patient got menses after 3 days of Matra Basti

Tab. Aloes Compound $1 \mathrm{BD}$ A/F with

02-12-2019 warm water

Rajah Pravartini vati 2 TDS A/F with warm water

Follow up after 1 month

Tab. Aloes Compound $1 \mathrm{BD}$ A/F with warm water

03-01-2020 Rajah Pravartini vati 2 TDS A/F with warm water

Follow up after 1 month

08-02-2020 Menses Regular, All Medicine stopped

\section{Discussion}

Artavakshaya is a vata pitta dominant artava vikara. Manitanance of agnideepana, Amapachana, and Vatanulomana along with nutritional supplementation through oral medications like rajapravartini vati, Aloes Compound and matra basti showed encouraging results in the artavakshaya, with improvement in the symptoms of vibandha. Thus, the results suggest that matra basti can be established as an effective treatment for most of the complaints related to artavakshaya.

\section{Mode of action of Matrabasti}

Matra basti normalizes apana vayu leading to vatanulomana and physiological functioning of vata, which may help in regularisation of menstruation and ovulation. basti dravya spreads all over the body, pacifies the aggravated dosha along with vyana vayu leads to samyaka rasa raktadi dhatu nirmana thus helps in artava utpatti and Pravritti. Basti being vatashamana and sthanika dosha in pakwashaya and artavavaha srotas in-turn helps in restoration of normal physiological function of female reproductive organs.

Matra basti after absorption reaches into systemic circulation and influences the endogenous opioids in the ENS specially endorphins ( $\beta$-endorphin) which in turn affect GnRH release regularizing HPO axis. Endogenous opioids are a group of peptides, which play an important role in the menstrual cycle through the inhibitory effect on GnRH secretion. $\beta$-endorphin been best known of the opioid related to the reproductive system regulating variety of pituitary hormones including gonadotrophins. $\beta$-endorphin has a role in the regulation of the normal menstrual cycle.(2)

\section{Probable mode of action of Tila Taila}

Tila Taila is of madhura rasa and vipaka, balya, and rasayana in karma; it nourishes and strengthens all the dhatus, checks dhatukshaya, and thus a $11 \mathrm{ev}$ iates vata. snigdha and guru guna decreases rukshata of vata(3) and with the help of ushna guna, and veerya it alleviates vata; the vikasi property reduces the spasms. sukskshmata dilates the channels and vishada prevents stickiness of the channels and thus helps in normal flow of menstrual blood. Garbhashaya shodhana, artavajanana properties (4) of Tila Taila indicates its specific action on genital tract and regulates function of Apana Vayu on particular system. Especially when administered in the form of basti, tila taila directly works on apana vata, and by its yonishula nashana action it works upon kashtartava. Sesame oil (tila taila) is a good source of vitamin E $(1.4 \mathrm{mg} / 100 \mathrm{~g})$ (5) and it also contains magnesium, copper, calcium, iron, zinc, and vitamin $\mathrm{B}_{6}$, It gives strength, nutrition, digestive power, detoxifies uterus, and has antioxidant properties. It is one of the best oils that can be applied on Vata Vyadhis.(6) Sesamum indicum L. is effective in inducing menstrual bleeding in women with oligomenorrhea. (7) 


\section{Conclusion}

In present case patient was with $\mathrm{h} / \mathrm{o}$ prolonged irregular menstruation and correction of the same was done through this treatment and relief of amenorrhea of 2 months which was not responding to oral medications, proved the efficacy of the intervention, thus the results are not by chance. The use of Matrabasti along with oral medication was found to be effective in the management of Artavakshaya. The suitable dietary modification and oral medications can effectively prevent the recurrence of artavakshaya.

\section{References}

1. Bachmann G A, E Kemmann, Prevalence of oligomenorrhea and amenorrhea in a college population, PMID: 7114117, https:// pubmed.ncbi.nlm.nih.gov/7114117/

2. Krupa R. Donga, Role of Nasya and Matra Basti with Narayana Taila on anovulatory factor, AYU, Jan-Mar 2013, Vol 34, Issue 1.
3. Sharma RK, Dash B, editors. Vol. 5. Varanasi: Chowkhamba Sanskrit Series Office; 2007. Agnivesha. Caraka Samhita; p. 68. [Google Scholar], https://www.ncbi.nlm.nih.gov/pmc/ articles/PMC3221063/ (1-6-2021, 02.21 pm)

4. Srikantha Murthy KR, editor. Vol. 1. Varanasi: Chaukambha Orientalia; 2004. Susruta. Susruta Samhita; p. 347. (Su/su/45/112) [Google Scholar], https://www.ncbi.nlm.nih.gov/pmc/articles/ PMC3221063/ (1-6-2021, 02.16 pm)

5. Sesame oil, Wikipedia, the free encyclopedia.com. [last retrieved on 2010 Jan 20]. Available from: http://www.sesame-oil.org . (1-6-2021, 02.15 $\mathrm{pm})$

6. https://www.researchgate.net/publication/ 336853488 TILA TAILA_A REVIEW (1-6-2021 11.50am)

7. https://sites.kowsarpub.com/semj/articles/ 20393.html (1-6-2021 12.34pm) 